論

日本金属学会誌 第 51 巻 第 9 号 (1987) 781-790

\title{
急冷した $\mathrm{Au}-\mathrm{Sb}$ 稀薄合金の回復過程における 空孔・溶質ペアの運動
}

\author{
田中 功* 高村仁一** 古川弘三*** 谷口裕一**** \\ 石田博章***** 竹下哲郎**** 亀井浩一****
}

J.Japan Inst.Metals, Vol.51,No.9(1987),pp.781-790

Motion of Vacancy-Solute Pairs in the Annealing Process of Quenched Au-Sb Dilute Alloys

Isao Tanaka*, Jin-ichi Takamura**, Kozo Furukawa***, Hirokazu Taniguchi**** Hiroaki Ishida*****, Tetsuro Takeshita**** and Koichi Kamei****

On isochronal annealing of quenched-in resistivity in dilute $\mathrm{Au}-\mathrm{Sb}$ alloys, very complicated annealing curves have been observed. This anomalous annealing behaviour is fully understood in terms of the consecutive motion of vacancy-solute (VS) pairs, owing to the strong binding between a vacancy and a solute atom, which leads to the successive formation and dissociation of multiple vacancy-solute complexes $V_{i} S_{j} \quad(i, j \geqq 1)$ during isochronal annealing. Main results obtained are summarized as follows: (1) The substantial part of the isochronal annealing curve in the dilute $\mathrm{Au}-\mathrm{Sb}$ alloy, as in the case of $\mathrm{Au}-\mathrm{Sn}$ alloy previously reported, can be described in terms of the motion of VS pairs, except for stage $\mathrm{X}$ ranging from 453 to $573 \mathrm{~K}$ in which an anomalously large resistivity drop occurred. (2) The binding energy of VS pairs was determined to be $0.43 \pm 0.05 \mathrm{eV}$, on the basis of the analysis of the effective migration energy in stage $\delta_{3}^{\prime}$ at which the dissociation of VS pairs is dominating. (3) From the analysis of the annealing kinetics in stage $\delta_{1}$, the migration energy of VS pairs was obtained as $0.59 \pm 0.02 \mathrm{eV}$, which is much smaller than the value of mono- or di-vacancies. (4) The frequency factor of the VS pair migration was found to be three orders of magnitude lower than that for mono-vacancy, which is due to the huge reduction in the frequency factor of the $\omega_{1}$ jump in terms of the five frequency jump model. (5) From the computer-simulation based on the reaction rate theory, during quenching and on subsequent annealing, the values of the binding energy, the resistivity contribution and the frequency factor of migration for various vacancy-solute complexes $V_{i} S_{j}(i, j \geqq 1)$ were determined.

(Received March 13, 1987)

Keywords: dilute gold-antimony alloys, quenched-in resistivity, annealing kinetics, motion of vacancy-solute pairs, vacancy-solute complexes, binding and migration energies

I.まえがき

合金における拡散を伴う諸現象の理解には，拡散の担い 手である原子空孔と溶質原子との相互作用を知るととが重
要である．稀薄合金では溶質原子間の相互作用が無視でき るので，空孔と溶質の相互作用を最む単純な形で抽出でき $ろ^{(1)}$. 仲田 ${ }^{(2)(3)}$ は，酸素などガス不純物の固溶度が他の 一価貴金属に比べて桁違いに小さい Au に，蒸着・拡散法

* 京都大学大学院生, 現在 : 大阪大学産業科学研究所 (Graduate Student, Kyoto University, Kyoto. Present address: The Institute of Scientific and Industrial Research, Osaka University, Ibaraki, Osaka)

** 京都大学工学部金属加工学教室, 現在 : 京都大学名誉教授; 新日本製鉄株式会社 (Department of Metal Science and Technology, Kyoto University, Kyoto. Present situation: Professor Emeritus of Kyoto University. Now at Nippon Steel Corporation, Tokyo)

*** 京都大学工学部金属加工学教室, 故人 (Department of Metal Science and Technology, Kyoto University, Kyoto. The deceased.)

**** 京都大学大学院生, 現在: 新日本製鉄株式会社(Graduate Student, Kyoto University, Kyoto. Present address : Nippon Steel Corporation, Tokyo)

***** 京都大学大学院生, 現在: 住友金属工業株式会社 (Graduate Student, Kyoto University, Kyoto. Present address : Sumitomo Metal Industries Ltd., Osaka) 
によって母材の純度を損ねる事なく種々の溶質原子を導入 して稀薄合金を作成し, 系統的に点欠陥と溶質原子との相 互作用を調べた。その結果，多価元素である $\mathrm{Sn}$ や Sbな どを導入した場合に，凍結空孔の回復過程に驚くべき異常 な現象を見いだした。Au-Sn合金については，以前に $\mathrm{Bass}^{(4)}$ 屯凍結空孔の等時焼鈍過程に, 純 $\mathrm{Au}$ にはみられ ない幾つかのステージの存在を報告しているが，解析は行 われていない，彼はまた急冷実験から，ての合金に打ける 見かけ上の空孔形成エネルギーが，純 $\mathrm{Au}$ のそれに比べて 明らかに小さい事を指摘している。乙れについては，後に Liu ら ${ }^{(5)}$ が解析して, 空孔と溶質原子との結合エネルギー を $0.45 \mathrm{eV}^{\dagger}$ と極めて大きな值にとれば，実験結果が良く 再現できることを示した. また, Herzig と Heumann ${ }^{(6)}$ は， $\mathrm{Au}$ 中での $\mathrm{Sn}$ や Sbの高温での拡散が，Au 中の自己 拡散に比べて著しく速いことを見いだし，空孔と多価元素 との間の強い相互作用を示唆した.

高村, 仲田ら ${ }^{(1)(3)(7)}$ は, 多価元素の $\mathrm{Sn}, \mathrm{Ge}$ および $\mathrm{Sb}$ を含む稀薄 $\mathrm{Au}$ 合金の急冷後の回復過程では，空孔と溶質 原子との結合力が極めて大きく，そのため空孔・溶質原子 対(VSペア)が解離することなくペアのまま連続運動を続 け，回復過程の各ステージを律速するてとを初めて明らか にした。すすおち，その回復曲線にみられる特異な複数の ステージは, VS ゚アアの運動に由来して, より高次な空孔・ 溶質複合体が次々と形成と分解とを繰り返すためであるて とを指摘した．乙れら一連の研究の総括的な報告はすでに なされているが(1)，個々の合金についての詳報はない．本 論文では，乙れら 3 種の合金の中であ際立って特異な回復 挙動を示す $\mathrm{Au}-\mathrm{Sb}$ 稀薄合金に関して, 空孔と溶質原子と の相互作用，とくに VSペアの特徵と，VSペアの運動に 由来する空孔・溶質複合体の形成亡分解の諸過程の計算機 シミュレーションによる回復曲線の解析とを中心に報告す る.

これらの結果は, 他の一価貴金属である $\mathrm{Cu}$ や $\mathrm{Ag}$ が多 価元素を含む場合にああてはまるものと考えられ，溶質拡 散の機構や凍結空孔による 2 次欠陥の形成機構によって重 要である。

\section{II. 実 験 方 法}

本研究で使用された試料は, 住友金属鉱山(株)に特注し て真空溶解により注意深く作成された高純度の Au-0.05 at $\% \mathrm{Sb}$ および Au-0.09at\% Sb 合金試料である.またて れらのほか, Au-0.05 at\% Sb 合金試料を $1073 \mathrm{~K}$ の空気 中にて $7.2 \mathrm{ks}$ 抢よび $28.8 \mathrm{ks}$ 焼鈍して酸化させ, 電気抵抗 的に検量される溶質としての $\mathrm{Sb}$ 濃度を $0.02 \mathrm{at} \%$ および 0.01 at \% にまで減少させた 2 種類の試料を屯, 必要に応 じ使用した。

測定に用いた試片は, すべて $0.5 \mathrm{~mm}$ 径の多結晶線で, 電気抵抗測定のため, その両端に電流および電圧測定用導 線として純 $\mathrm{Au}$ 線(99.999\%，0.2 mm 径)が点溶接され, さらに急冷・焼鈍等に際して試片が変形するてとがないよ うに石英枠に固定された。電圧測定用導線の間隔は約 60

$\dagger 1 \mathrm{eV}=1.6022 \times 10^{-19} \mathrm{~J}$. $\mathrm{mm}$ に統一された．凍結空孔を導入するための試片の急 冷は，純化したへリウムガスを満たした縦型炉から，バル ブを開くと同時に $253 \mathrm{~K}$ の飽和食塩水に自然落下させる ことによって行われた。こてで高純度のヘリウム雾囲気を 用いたのは，溶質原子の内部酸化を防ぐためである。

急冷された試片は, 直ちに $253 \mathrm{~K}$ のアセンンで洗浄後 液体窒素に浸漬され, 電気抵抗の測定に供された。急冷の 瞬間から試片が液体窒素に入るまでの所要時間は $5 \mathrm{~s}$ で, この時間は常に一定になるように留意した。電気抵抗測定 は擋拌されている液体窒素中で行われ, 液体窒素の微小な 温度变化は, 各測定ごとに純 $\mathrm{Au}$ 線のダミー試片の電気抵 抗を基準にして，厳密に補正された，以上の手法による本 実験の電気抵抗測定䛊差は, $\pm 0.1 \mathrm{p} \Omega \cdot \mathrm{m}$ である.

なお，等時焼鈍に用いた浴槽は， $363 \mathrm{~K}$ までは純水，乙 れ以上 $523 \mathrm{~K}$ までの間は精製大豆油，それ以上 $650 \mathrm{~K}$ ま ではシリコーン油である。シリコーン油を用いた場合には, 次の焼鈍前に熱塩酸で十分に洗浄し，不純物の混入防止に 注意した。

\section{III. 実 験 結 果}

\section{Au-Sn 合金との対比}

原子空孔と溶質原子との結合力が極めて強いときには， 急冷後の回復過程に拈いて, 原子空孔 $(\mathrm{V})$ と溶質原子 $(\mathrm{S})$ とが解離することなくペアのまま連続運動を続けることが 指摘されている(1)(3)(7). Fig.1は， $873 \mathrm{~K} よ り$ 急冷された $\mathrm{Au}-0.1$ at $\% \mathrm{Sn}$ 合金を $10 \mathrm{~K}$ の温度間隔で $180 \mathrm{~s}$ ずつ等時 焼鈍したときの電気抵抗曲線で, 純 $\mathrm{Au}$ の場合に比べて驚 くほど複雑である.

注目すべきことは，まず，回復の各ステージにおいて実 験的に求められた移動の活性化エネルギー $E_{\text {eff }}$ が, $\delta_{1}, \delta_{2}$ および $\delta_{3}$ のいずれのステージにおいても $0.57 \mathrm{eV}$ 前後の 同じ値を持つことである. この值は, 純 $\mathrm{Au}$ 中の単一空孔 $(\mathrm{V})$ の移動エネルギー $(0.85 \mathrm{eV})$ はもとより, 複空孔 $\left(\mathrm{V}_{2}\right)$

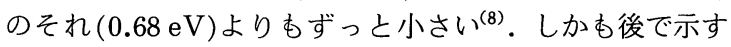
例(Fig.11 参照)からあ理解されるように, Au-0.1 at\% Sn

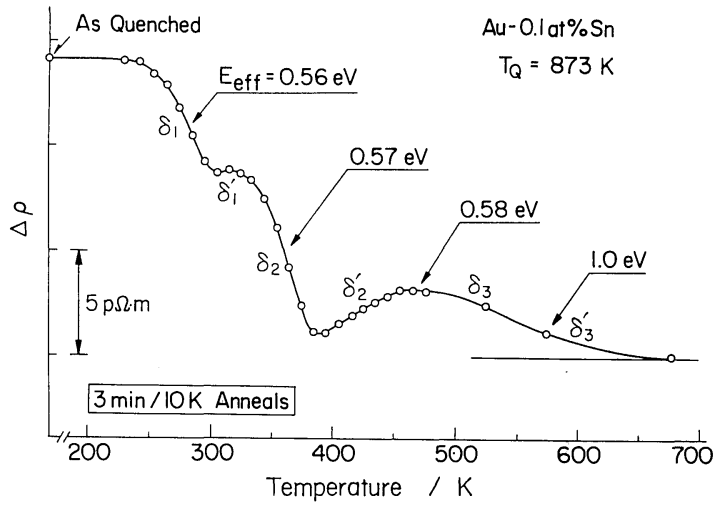

Fig.1 The change in the quenched-in resistivity on isochronal annealing in a $\mathrm{Au}-0.1$ at $\% \mathrm{Sn}$ alloy quenched from $873 \mathrm{~K}$. Note that the resistivity curve consists of several stages including reverse annealing stages $\delta_{1}^{\prime}$ and $\delta_{2}^{\prime}$. 
合金の $873 \mathrm{~K}$ からの急冷材における凍結空孔の大部分は, 単一の空孔と溶質原子の対，すなわち VSペアとして存在 し，その他にはVSペアの運動により形成されるより高次 の複合体の $\mathrm{VS}_{2}$ や $\mathrm{V}_{2} \mathrm{~S}_{2}$ が少量凍結されているのみであ る. 従って, 急冷後の最初のステージ $\delta_{1}$ の回復を律速す るのはVSペアであり，その移動エネルギーが $0.56 \mathrm{eV}$ で あることから考えて，ほぼ同じ $E_{\text {eff }}$ を示す $\delta_{2} や \delta_{3}$ のス テージにおいても VS ペアの運動が律速しているてとが結 論された ${ }^{(1)(3)}$. 但し, 回復過程の最後の温度域の $\delta_{3}^{\prime}(>533$ $\mathrm{K})$ では， $E_{\text {eff }}$ として $1.0 \mathrm{eV}$ という值が得られる(Fig.1).

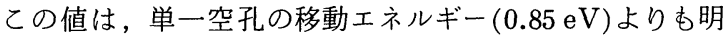
らかに大きい。乙のことは，乙の温度域に到って初めて $\mathrm{VS}$ ペアの分解反応 $(\mathrm{VS} \rightarrow \mathrm{V}+\mathrm{S}, \mathrm{V} \rightarrow \operatorname{sinks}$ ) が進行する ことを示している，VSペアがてのような高温で初めて解 離するという事実は，空孔・溶質の結合力がきわめて大き い事を示唆するものであり, 実際ての温度領域での実験結 果の詳細な解析によって, $\mathrm{Au}-\mathrm{Sn}$ 合金における VSペア の結合エネルギーとして $0.40 \pm 0.05 \mathrm{eV}$ という值が得ら れている(1).

以上のように，急冷された稀薄合金にみられる複雑な電 気抵抗変化を示す等時焼鈍回復曲線は, VSペアの運動を 律速過程として, Table 1 亿示す諸反応によって見事に 解明されている(1).乙れによると $\delta_{1}, \delta_{2}$ および $\delta_{3}$ の各ス テージは，右向き矢印の反応で，次第に高次の空孔・溶質 複合体が形成される段階であり， $\delta_{1}^{\prime}$ と $\delta_{2}^{\prime}$ は, 左向きの反 応で, 乙れらの分解過程である. また $\delta_{3}^{\prime}$ は, 上述のよう に, $\mathrm{V}_{3}$ 複合体の解離によって生じた VSペアの分解過程 であると共に, 解離反応で発生したばかりの VS ペアある いはその分解生成物の $\mathrm{V}$ 之, 未分解の $\mathrm{V}_{3}$ 複合体との反 応による，高次でより安定な複合体 $\mathrm{V}_{\mathrm{i}} \mathrm{S}_{\mathrm{j}}(\mathrm{i}, \mathrm{j} \geqq 4)$ の形成 過程であある。乙の間の事情は， $\delta_{1}^{\prime}$ および $\delta_{2}^{\prime}$ のステージ であ同様である.

このように強い空孔・溶質の結合力に起因する VSペア の運動は，Snよりも多価である Sb を含む稀薄合金にお いてあ観察されることが期待される。なぜならば，空孔と 溶質との結合力の支配的因子は溶質の原子価であるからで ある ${ }^{(9)}$. しかし，実際に Au-Sb 合金について測定してみ

Table 1 Vacancy reactions in each stage of isochronal annealing of quenched-in resistivity in the dilute $\mathrm{Au}-\mathrm{Sb}$ alloy, where $\mathrm{V}$ and $\mathrm{S}$ are mono-vacancy and single solute atom, respectively.

\begin{tabular}{|c|c|c|}
\hline$\delta_{1}$ & $\mathrm{VS}+\mathrm{S} \rightleftarrows \mathrm{VS}_{2}$ & $\delta_{1}^{\prime}$ \\
\hline$\delta_{2}$ & $\begin{aligned} & \mathrm{VS}+\mathrm{VSS}^{\rightleftarrows} \rightleftarrows \mathrm{V}_{2} \mathrm{~S}_{2} \\
& \mathrm{VS}+\mathrm{VS}_{2} \rightleftarrows \mathrm{V}_{2} \mathrm{~S}_{3} \\
& \mathrm{VS} \rightarrow \operatorname{sinks}\end{aligned}$ & $\delta_{2}^{\prime}$ \\
\hline$\delta_{3}$ & $\begin{array}{c}\mathrm{VS}+\mathrm{V}_{2} \mathrm{~S}_{2} \rightarrow \mathrm{V}_{3} \mathrm{~S}_{3} \\
\mathrm{VS}+\mathrm{V}_{2} \mathrm{~S}_{3} \rightarrow \mathrm{V}_{3} \mathrm{~S}_{4} \\
\mathrm{VS} \rightarrow \operatorname{sinks}\end{array}$ & \\
\hline$\delta_{3}^{\prime}$ & $\begin{aligned} \mathrm{V}_{3} \mathrm{~S}_{3}, & \mathrm{~V}_{3} \mathrm{~S}_{4} \\
\mathrm{VS} & \rightarrow \mathrm{VS}, \mathrm{S} \\
\mathrm{V}_{3} \mathrm{~S}_{3}, & \mathrm{~V}_{3} \mathrm{~S}_{4}, \mathrm{~V}+\mathrm{VS}, \mathrm{V} \\
& \rightarrow \mathrm{V}_{\mathrm{i}} \mathrm{S}_{\mathrm{j}}(\mathrm{i}, \mathrm{j} \geqq 4) \\
\mathrm{VS}, \mathrm{V} & \rightarrow \operatorname{sinks}\end{aligned}$ & \\
\hline
\end{tabular}

る亡, その等時焼鈍回復曲線における電気抵抗の変化は, 極めて異常である. その特異さは, 純 $\mathrm{Au}$ および $\mathrm{Au}-\mathrm{Sn}$ 合金と対比して示した Fig.2からあ明瞭である.乙のよ うな著しい相違にも拘らず，以下の節で次第に明らかとな るように，全体としての $\mathrm{Au}-\mathrm{Sb}$ 系の回復挙動は，驚くほ ご $\mathrm{Au}-\mathrm{Sn}$ 系に類似している。

Fig.2の Au-0.05 at\% Sb 合金の曲線は, $873 \mathrm{~K}$ から急 冷の後， $\mathrm{Au}$ 抒よび $\mathrm{Au}-0.1$ at $\% \mathrm{Sn}$ 合金と同じく $10 \mathrm{~K}$ の 温度間隔で $180 \mathrm{~s}$ ずつの等時焼鈍を施したが，電気抵抗の 測定自身は $\mathrm{Au}$ や Au-Sn とは異なり $20 \mathrm{~K}$ 間隔で行った あのである．図中の水平な細い実線は，基準となる焼鈍材 のレベルを示すすので，試片を $633 \mathrm{~K}$ で $300 \mathrm{~s}$ 保持した後， この温度から急冷した状態での電気抵抗値である。乙の温 度での熱平衡空孔量は無視しうるほよ゙少ないので, この状 態を以降, 完全焼鈍状態と称する. $873 \mathrm{~K}$ から急冷して凍 結空孔を導入した後, 直ちに $633 \mathrm{~K} に て$ 等温焼鈍した場 合には約 $10 \mathrm{~s}$ で電気抵抗がての完全焼鈍状態に達したの で，乙の状態を基準に用いる事は妥当と思われる。

$\mathrm{Au}-\mathrm{Sb}$ 系合金における凍結空孔の回復曲線の解析に当 たり，Au-Sn 系合金との対比において最む困惑したのは， $453 \mathrm{~K}$ から始まる深い谷間を持つステージの存在であった。 真因の明らかでないてのステージをここでは $\mathrm{X}$ とよぶ. その形成と特徴については次節で述べるが，結局てのステー ジ X $\mathrm{Au}-\mathrm{Sb}$ 系にのみ特有な存在であることが判明し た.

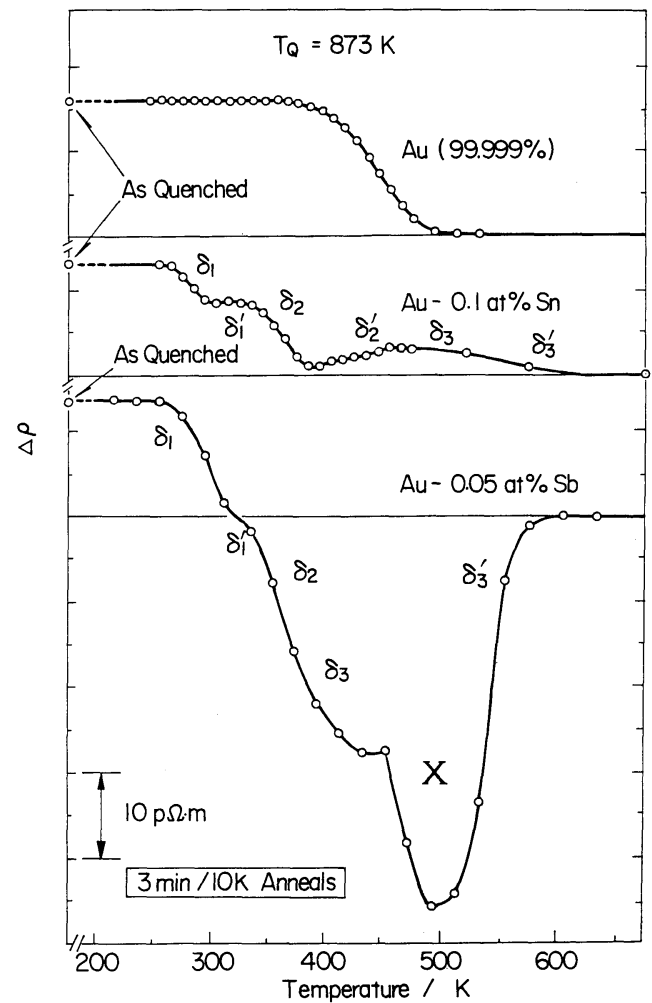

Fig.2 Changes in the quenched-in resistivity on isochronal annealing of pure gold and dilute gold alloy specimens quenched from $873 \mathrm{~K}$. Note that the curve for pure gold is simple while the curve for the Au-Sb alloy is very complicated. 


\section{Au-Sb 系に特異なステージ $\mathrm{X}$}

$\mathrm{Au}-\mathrm{Sb}$ 合金の回復曲線之 $\mathrm{Au}-\mathrm{Sn}$ 合金のそれとの大き な相違は，前述したように，ステージXの存在である. このステージは，Au-Sn 合金にあ Au-Ge 合金であ観察 されず(1)，Au-Sb 合金に特有なあのである。その本性は 不明であるが，その出現の条件は以下に示す通りである.

ステージXの出現は, 溶質濃度や急冷温度に対して敏 感である.Fig. 3 は，溶質濃度の異なる 3 種類の合金を $873 \mathrm{~K}$ から急冷した場合の等時焼鈍曲線を比較したもので ある. 溶質濃度の増加とともにステージ X は顕著となる。 Fig.4 亿は同一濃度の Au-0.05at\% Sb 合金について, 急 冷温度を変えた場合の結果を示した。凍結空孔量が多いほ どステージ Xでの電気抵抗変化は顕著となり，またその 温度領域屯高温側に拡大している。逆に言えば，溶質濃度 が低く，また急冷温度が低いと，ステージXは出現しに くくなる.Fig. 5 には，低濃度の Au- 0.01 at\% Sb 合金を 比較的低温の $823 \mathrm{~K}$ より急冷した場合の回復曲線を示し たが，ステージXはほぼ消失し，回復曲線全体の Au-Sn 合金のそれとの類似性は高まっている。

ステージXに示される電気抵抗率の急激な減少の原因 として, 念頭に浮かぶのは, 溶質の不均質析出である. あ しそうならば，加工により転位を導入すれば，乙の現象は 加速されるはずである．Fig.6は，Au-0.05 at\% Sb 合金 を $873 \mathrm{~K}$ より急冷後液体窒素中で $1.5 \%$ の引張変形を加 えた試片と, 急冷したのみで変形を施さない試片とを比較 したものである. 図から明らかなように，転位の導入によっ てステージXは逆に消失した。従って, 溶質の不均質析

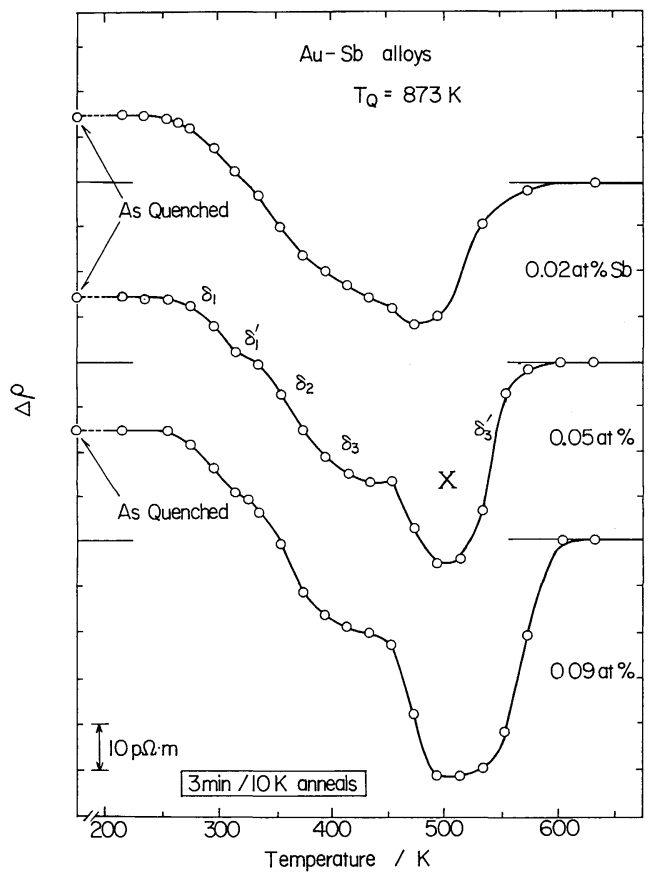

Fig.3 Effect of the solute concentration on the appearance of stage $\mathrm{X}$ in the isochronal annealing curve of dilute $\mathrm{Au}-\mathrm{Sb}$ alloys quenched from $873 \mathrm{~K}$.

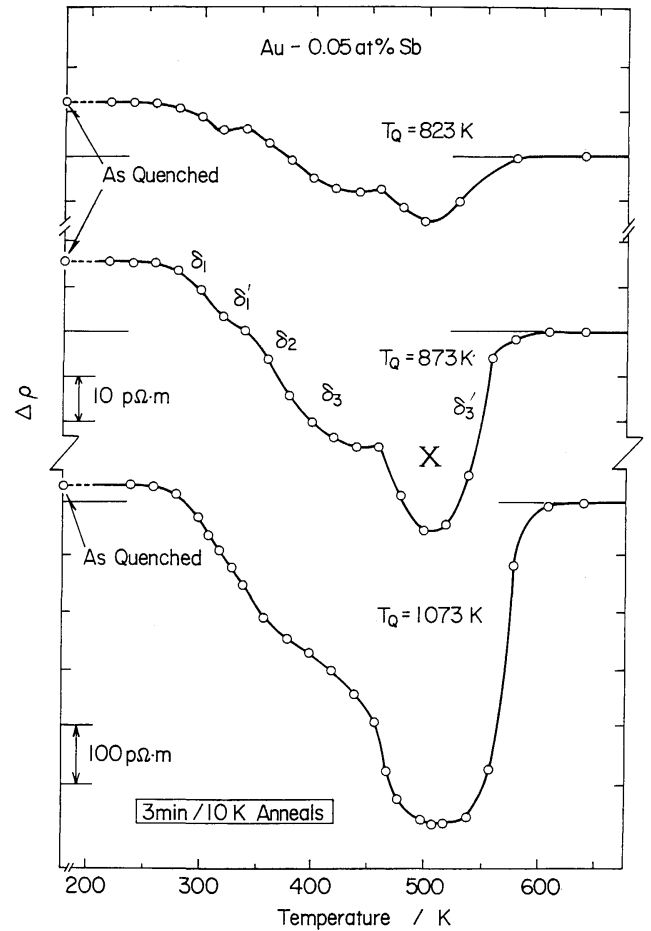

Fig.4 Effect of the quenching temperature on the appearance of stage $\mathrm{X}$ in a $\mathrm{Au}-0.05 \mathrm{at} \% \mathrm{Sb}$ alloy. Note that the scale of resistivity is different only for the bottom curve.

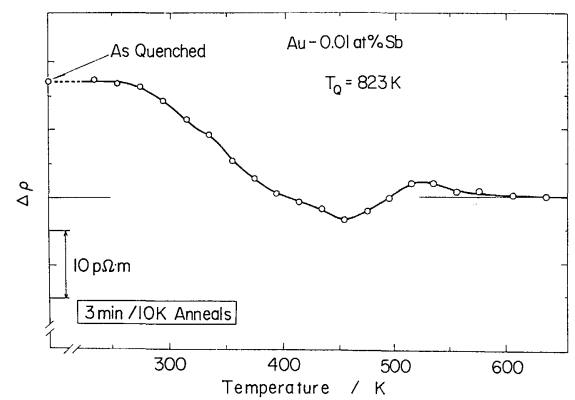

Fig.5 Isochronal annealing curve of a $\mathrm{Au}-0.01$ at\% $\mathrm{Sb}$ alloy quenched from $823 \mathrm{~K}$.

出がてのステージの原因ではないととが結論される。なお， ステージ $\delta_{2}$ まで弱加工の効果が現れないのは, Table 1 に示す空孔・溶質間の反応飞要する拡散距離と転位密度と の相対関係任因るあのである。また，急冷後ステージ X 直前の $433 \mathrm{~K}$ まで等時焼鈍したのち $523 \mathrm{~K}$ の油槽に急熱 すると，瞬時にして電気抵抗率の急激な減少，すなわちス テージXが再現される。乙れらの事実を総合して考えて みると, 電気抵抗率の異常な低下を特徵とするステージ X の出現は, $\mathrm{Au}-\mathrm{Sb}$ 系に特有な規則的配列之構造緩和を有 する空孔・溶質複合体, $V_{i} S_{j}(i, j \geqq 4)$ の形成に伴う現象 と推論される.

てのように，ステージ X は $\mathrm{Au}-\mathrm{Sb}$ 系のみに見られる 特異な現象であり, てのステージの本性について興味は残 るが, 本研究の本筋ではない, 従って本研究では, ステー 


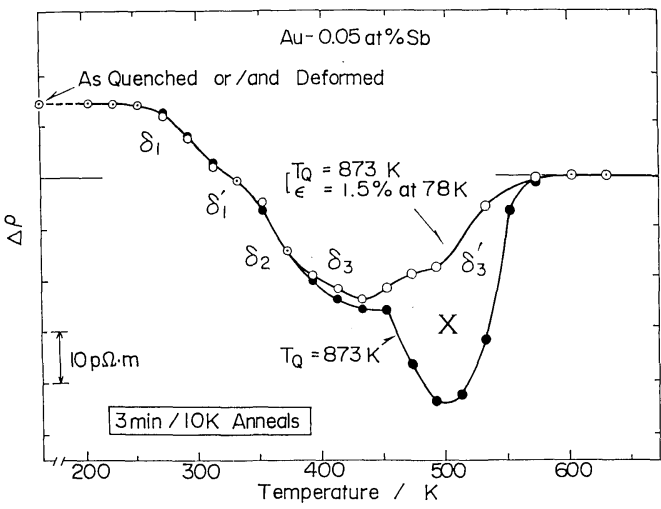

Fig.6 Isochronal annealing curves for two specimens of $\mathrm{Au}-0.05$ at\% Sb alloy quenched from 873 $\mathrm{K}$ or/and subsequently deformed in tension by $1.5 \%$ at $78 \mathrm{~K}$.

ジ Xが出現しないような条件, 例えば Fig.5の曲線や Fig.6の白丸を結ぶ曲線を用いて解析を進め，Au-Sn 系 合金との対応を明らかにしてゆくことにする.

\section{VSペアの移動エネルギーおよび振動項}

この稀薄合金の凍結空孔の回復過程が VSペアの運動に 律速されるむのであることを明確にするために，まず次の 1 次反応で記述されるステージ $\delta_{1}^{(1)}$ で等温焼鈍を行った.

$$
\mathrm{VS}+\mathrm{S} \longrightarrow \mathrm{VS}_{2}
$$

Fig.7 に Au- 0.05 at $\% \mathrm{Sb}$ 合金試片を $873 \mathrm{~K}$ から急冷し たのち, $273 \mathrm{~K}$ から $303 \mathrm{~K}$ までの各温度で等温焼鈍を施し たときの電気抵抗率の変化を示す. 図中の $\Delta \rho$ は, 完全焼 鈍状態を零としたときの電気抵抗率の値であり, 縦軸は急 冷による電気抵抗率の増加量 $\Delta \rho_{0}$ によって規格化されて

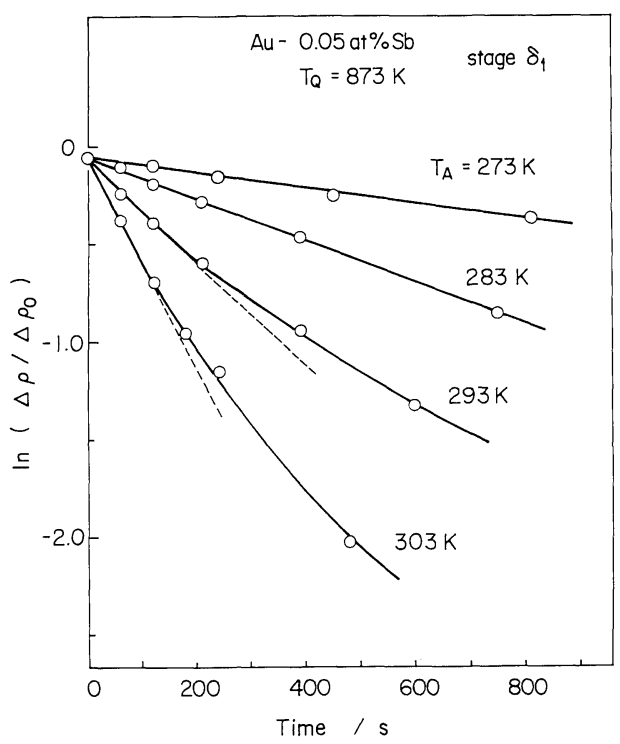

Fig.7 The logarithmic plot of the resistivity change against the isothermal annealing time for stage $\delta_{1}$ in the $\mathrm{Au}-0.05$ at $\% \mathrm{Sb}$ alloy quenched from $873 \mathrm{~K}$.
いる.なお Fig.7では, 急冷後の初期状態を揃えるため に, 各温度での等温焼鈍に先立って試片に $273 \mathrm{~K}$ で $180 \mathrm{~s}$ の焼鈍を施した。

ステージ $\delta_{1}$ に打ける空孔反応は, 主要な反応である $\mathrm{VS}_{2}$ の形成反応の他に, ステージ $\delta_{1}$ の後半に扣いて重要 となる $\mathrm{VS}_{2}$ の分解反応 (式 (1) の逆反応)を併せると, ス テージ $\delta_{1}$ の後半まで正確に記述される. 焼鈍の初期では 式 ( 1 )の反応が優勢なので, 時刻 $t$ における電気抵抗変化 は次式で近似される。

$$
\begin{array}{ll}
\text { ここで } & \ln \left(\Delta \rho / \Delta \rho_{0}\right)=-K_{0} C_{\mathrm{S}} t \\
& K_{0}=A \exp \left(-E_{\mathrm{vS}}^{\mathrm{M}} / k T\right)
\end{array}
$$

であり, $C_{\mathrm{S}}$ は溶質濃度, $E_{\mathrm{VS}}^{\mathrm{M}}$ はVS ゚゚アの移動エネルギー である. 因子 $A$ は, 式 (1)の反応の幾何学因子と VS ペ ア運動の有効振動数 ${ }^{(10)}$ との積であり, 以後振動項と呼ぶ.

式 (2) は Fig.7 の焼鈍初期に見られる直線部分に対応 するむのである。焼鈍が進み $\mathrm{VS}_{2}$ の濃度が増加すると， その分解反応は無視し得なくなり, 式(2)の直線関係から 偏倚する。

焼鈍初期に式 (2)の直線関係から求めた勾配 $K_{0} C_{\mathrm{S}}$ を アレニウス,プロットした結果を Fig. 8 に示す. 同様の 実験は，Au-0.05 at\% Sb 合金のほかに Au-0.09 at\% Sb 合金についても行われ，その結果を図中に併せて示した. この直線の傾きから $E_{\mathrm{VS}}^{\mathrm{M}}$ が, また縦軸との切片から $A$ の 值が評価される. 最小自乗法により, 次の值が得られた.

$$
\begin{aligned}
E_{\mathrm{VS}}^{\mathrm{M}} & =0.59 \pm 0.02 \mathrm{eV} \\
A & =6_{-3}^{+6} \times 10^{10} \mathrm{~s}^{-1}
\end{aligned}
$$

この移動エネルギーは, $\mathrm{Au}$ 中の単一空孔の移動エネル ギー $(0.85 \mathrm{eV})$ や複空孔のそれ $(0.68 \mathrm{eV})$ よりあ小さく ${ }^{(8)}$, $\mathrm{Au}-\mathrm{Sn}$ 合金の場合と同様に, VSペアの移動がステージ $\delta_{1}$ の空孔反応を律速しているてとを示すあのである. ま た $A$ の值は $\mathrm{Au}$ 中の単一空孔や複空孔の移動の際の振動 項に比べておよそ 3 桁ほよ゙小さい. これらのことは, 多価 溶質元素を含む稀薄 $\mathrm{Au}$ 合金の大きな特徴である ${ }^{(1)}$.

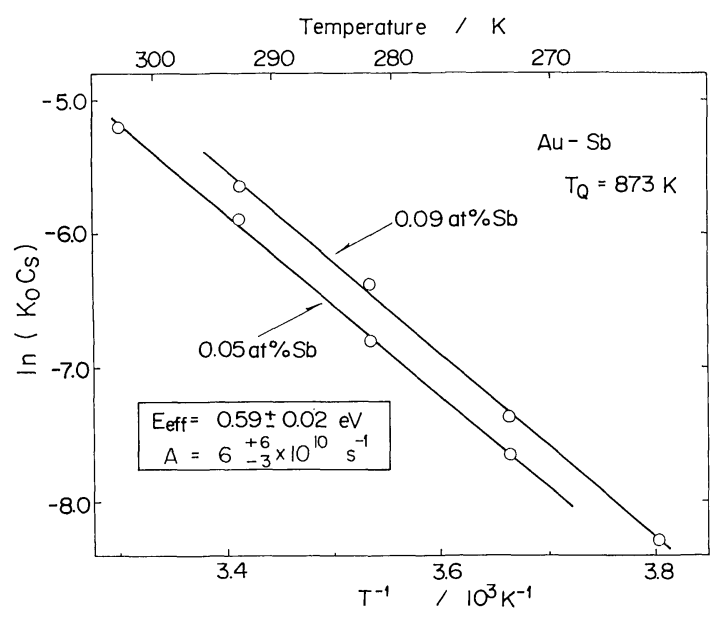

Fig.8 The Arrhenius plot of the decay rate of quenched-in resistivity in stage $\delta_{1}$ of $\mathrm{Au}-0.05$ at $\%$ and 0.09 at $\% \mathrm{Sb}$ alloys. 


\section{4. ステージ $\boldsymbol{\delta}_{2}$ および $\boldsymbol{\delta}_{3}$}

急冷した $\mathrm{Au}-\mathrm{Sb}$ 合金の電気抵抗回復曲線には, $\mathrm{Au}-\mathrm{Sn}$ 合金にみられるステージ $\delta_{2}^{\prime} に$ 相当する逆回復のステージ はほとんど見られない，乙のため，電気抵抗測定だけから では複空孔型空孔・溶質複合体 $\left(\mathrm{V}_{2} \mathrm{~S}_{\mathrm{j}}, \mathrm{j}=2,3\right)$ が形成され るステージ $\delta_{2}$ と, 三重空孔型複合体 $\left(\mathrm{V}_{3} \mathrm{~S}_{\mathrm{i}}, \mathrm{j}=3,4\right)$ が形 成されるステージ $\delta_{3}$ 之(Table 1 参照)の温度領域の境界 を知ることができない，そこで，高村，白井ら ${ }^{(1)(11)}$ にっっ て行われた同じ組成の試料についての陽電子寿命測定結果 を利用する。

一般に空孔型欠陥に捕捉された陽電子の寿命は，空孔集 合体の空隙の大きさに対し非常に敏感である ${ }^{(12)}$. 白井ら ${ }^{(7)}$ は, $\mathrm{Au}-0.1 \mathrm{at} \% \mathrm{Sn}$ 合金を $873 \mathrm{~K}$ から急冷した試料につ いて, Fig.1 亿示された電気抵抗測定の場合之同一の等時 焼鈍を行い，陽電子寿命を測定した。その結果を Fig.9 示す。陽電子の平均寿命は, ステージ $\delta_{1}$ の温度領域で はほぼ一定であるが, $\mathrm{V}_{2}$ 型の空孔・溶質複合体が形成さ れるステージ $\delta_{2}$ になると長くなり，ステージ $\delta_{2}$ の終了温 度で最む長い値を示す．それより高温の $\delta_{3}$ では，陽電子 寿命の短い $\mathrm{V}_{3}$ 型空孔・溶質複合体が形成されるので, 平 均寿命は減少している(1). ての結果は, 電気抵抗測定によっ て決定された空孔反応 (Table 1) と極めて良く対応した。

同様に，Au-0.05at\% Sb 合金試片についても，同じよ うな方法で陽電子寿命が測定され ${ }^{(11)(13)}$ ，その結果が Fig. 9 亿併せて示してある. 陽電子の平均寿命は, ステージ $\delta_{2}$ の開始する $333 \mathrm{~K}$ 付近から長くなりはじめ, 373〜 383 K でピークに達した以後減少に転じた. 従って, ての付近が ステージ $\delta_{2}$ と $\delta_{3}$ との境界の温度である.なお, Fig.9 亿 おけるピーク寿命後の変化が両曲線で異なるのは， $\delta_{3}$ 以 上で形成される空孔・溶質複合体 $\mathrm{V}_{\mathrm{i}} \mathrm{S}_{\mathrm{j}}(\mathrm{i}, \mathrm{j} \geqq 3)$ の性質

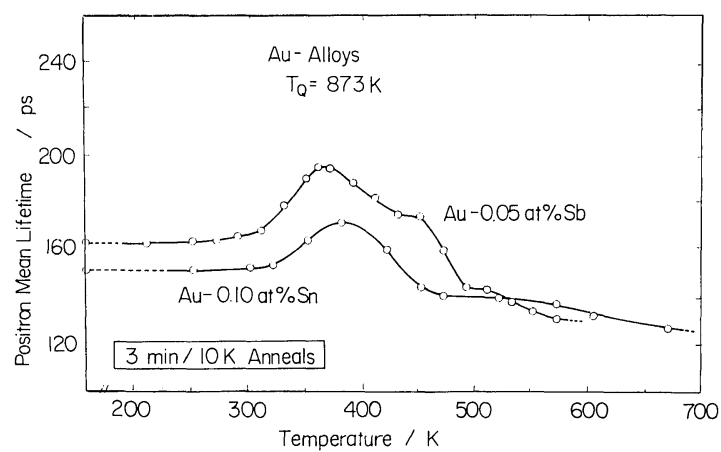

Fig.9 Changes in positron mean lifetimes on isochronal annealing for $\mathrm{Au}-0.1 \mathrm{at} \% \mathrm{Sn}$ and $\mathrm{Au}-$ $0.05 \mathrm{at} \% \mathrm{Sb}$ alloys which were quenched from 873 $\mathrm{K}$.

Table 2 The temperature range of each stage in the isochronal annealing curve of the $\mathrm{Au}-0.05$ at $\% \mathrm{Sb}$ alloy quenched from $873 \mathrm{~K}$.

\begin{tabular}{l|c|c|c|c|c|c}
\hline \hline Stage & $\delta_{1}$ & $\delta_{1}^{\prime}$ & $\delta_{2}$ & $\delta_{2}^{\prime}$ & $\delta_{3}$ & $\delta_{3}^{\prime}$ \\
\hline $\begin{array}{l}\text { Tempera- } \\
\text { ture } / \mathrm{K}\end{array}$ & $253 \sim 313$ & $313 \sim 333$ & $333 \sim 373$ & - & $393 \sim 433$ & $433 \sim 633$ \\
\hline
\end{tabular}

(積層欠陥四面体とボイドとの存在比)の差によるあのであ $3^{(1)(14)}$.

以上の解析結果を総合して, $\mathrm{Au}-0.05 \mathrm{at} \% \mathrm{Sb}$ 合金の場 合の回復曲線の各ステージの温度領域を区分したのが Table 2である.乙こでは, Au-Sn 合金との対応を重視 して, Au-Sb 合金に特有なステージ X は除外してある (Fig.6参照).

\section{VSペアの結合エネルギー}

VSペアの結合エネルギーを求めるには，VSペアの分 解が盛んになるステージでの活性化エネルギーを知る必要 がある.このステージは $\delta_{3}^{\prime}$ であり，Fig.10は，Au-0.01 at\% Sb 合金を $823 \mathrm{~K}$ から急冷した後, $553 \mathrm{~K}$ から $593 \mathrm{~K}$ の間で等温焼鈍し (Fig.5 参照), 特異なステージ X の出 現しない条件で, 活性化エネルギーを求めたあのである. その値は $1.1 \mathrm{eV}$ 前後で, $\mathrm{Au}-\mathrm{Sn}$ 合金の場合と同様化 ${ }^{(1)}$, VSペアの強い結合力を示唆している.

このステージ $\delta_{3}^{\prime}$ では, VS ペアの分解反応とと屯に，V や VS ペアの消滅源への到達や，上り高次の空孔・溶質複 合体 $V_{i} S_{j}(i, j \geqq 4) へ の$ 合体が扔てる. 実験的に求められ た活性化エネルギーと関連する反応は，次式で記述される。

$$
\begin{aligned}
& \mathrm{VS} \underset{K_{2}}{\stackrel{K_{1}}{\rightleftarrows}} \mathrm{V}+\mathrm{S} \\
& \mathrm{VS} \stackrel{K_{3}}{\longrightarrow} \operatorname{sinks} \\
& \mathrm{V} \stackrel{K_{4}}{\longrightarrow} \operatorname{sinks}
\end{aligned}
$$

ここで $K_{1} \sim K_{4}$ は各反応の速度係数であり，それぞれ $\mathrm{V}, \mathrm{VS}$ の移動エネルギー $E_{\mathrm{V}}^{\mathrm{M}}, E_{\mathrm{VS}}^{\mathrm{M}}$ ，あるいは VSぺアの 結合エネルギー $E_{\mathrm{VS}}^{\mathrm{B}}$ 等を含んでいる.

乙の空孔反応自身は, Damask とDienes ${ }^{(15)}$ や Chik $^{(16)}$ によって提案されたあのと同じ形である. しかし，ての反 応が空孔と溶質原子との結合力が極めて強い場合に実際に 適用できることを示したのは, 高村と仲田ら ${ }^{(1)(3)}$ の解析結 果が最初である. VS ペアの分解反応の活性化エネルギー は単一空孔の移動エネルギー $E_{\mathrm{V}}^{\mathrm{M}}(=0.85 \mathrm{eV})$ よりも, $E_{\mathrm{VS}}^{\mathrm{B}}$ だけ大きいが, 実際の回復過程では, 式(6-2) 抢よび(6-3) の反応が同時に進行している. てのため, 活性化エネルギー の実験値， $E_{\text {eff }}$ からの $E_{\mathrm{VS}}^{\mathrm{B}}$ の值の評価は，以下のように して行われた.

ステージ $\delta_{3}^{\prime}$ 後半のように空孔の易動度が十分に大きい

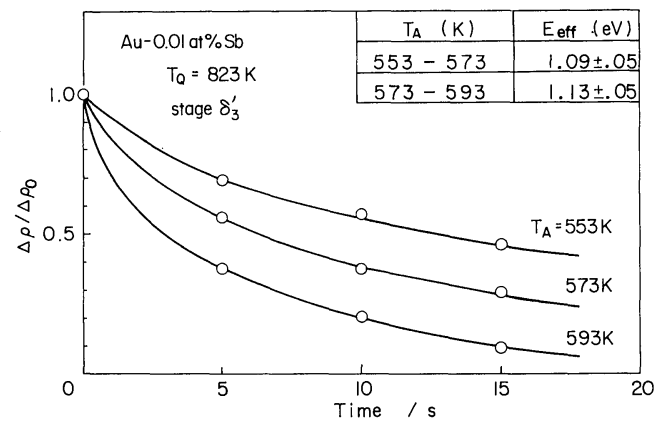

Fig.10 Isothermal annealing curves in stage $\delta_{3}^{\prime}$ of a $\mathrm{Au}-0.01 \mathrm{at} \% \mathrm{Sb}$ alloy quenched from $823 \mathrm{~K}$. The effective migration energies obtained are listed in the figure. 
温度域では, 式(6-1)の動的平衡, すなわち次式(7)の関 係は, 実験温度の $573 \mathrm{~K}$ では焼鈍開始後 $10^{-3} \mathrm{~s}$ 程度の極 めて短い時間で達成される.

$$
K_{1} C_{\mathrm{vs}}=K_{2} C_{\mathrm{v}} C_{\mathrm{S}}
$$

こてで, $C_{\mathrm{V}}, C_{\mathrm{S}}, C_{\mathrm{VS}}$ はそれぞれ単一空孔 $(\mathrm{V})$, 溶質 原子 $(\mathrm{S})$ および $\mathrm{VS}$ ペアの濃度である.乙の動的平衡条件 のもとでは, 次の解析解が導かれる.

$$
\begin{gathered}
C_{\mathrm{V}}=C_{\mathrm{V}}^{0} \exp \left(-K_{\text {eff }} \cdot t\right) \\
\text { ここで } \\
K_{\text {eff }}=\left(K_{1} K_{4}+K_{2} K_{3} C_{\mathrm{S}}\right) /\left(K_{1}+K_{2} C_{\mathrm{S}}\right)
\end{gathered}
$$

である. $C_{\mathrm{V}}^{0}$ は動的平衡条件が達成された時刻での $\mathrm{V}$ の濃 度を表し, 乙の時刻が焼鈍時間 $t=0$ に相当する.式(8) 亡(9)から見かけの移動の活性化エネルギー $E_{\text {eff }}$ は, VS と $\mathrm{V}$ の振動項の比を $f=\nu_{\mathrm{VS}}^{*} / \nu_{\mathrm{V}}^{*}$ とすれば, 次式で与え られる。

$$
\begin{aligned}
E_{\mathrm{eff}}= & -\partial \ln K_{\mathrm{eff}} / \partial(1 / k T) \\
= & E_{\mathrm{V}}^{\mathrm{M}}-\frac{12 C_{\mathrm{S}} f E_{0} \exp \left(G_{0} / k T\right)}{1+12 C_{\mathrm{S}} f \exp \left(G_{0} / k T\right)} \\
& +\frac{12 C_{\mathrm{S}} E_{\mathrm{VS}}^{\mathrm{B}} \exp \left(G_{\mathrm{VS}}^{\mathrm{B}} / k T\right)}{1+12 C_{\mathrm{S}} \exp \left(G_{\mathrm{VS}}^{\mathrm{B}} / k T\right)}
\end{aligned}
$$

ここで $G$ は自由エネルギー， $E$ はエンタルピーを表し， $G_{0}$ と $E_{0}$ は次式で与えられる.

$$
\begin{aligned}
& G_{0}=G_{\mathrm{V}}^{\mathrm{M}}-G_{\mathrm{VS}}^{\mathrm{M}}+G_{\mathrm{VS}}^{\mathrm{B}} \\
& E_{0}=E_{\mathrm{V}}^{\mathrm{M}}-E_{\mathrm{Vs}}^{\mathrm{M}}+E_{\mathrm{VS}}^{\mathrm{B}}
\end{aligned}
$$

実験的に求められた Fig.10の結果は，式(10)に沶いて 次の値の時に最む良く再現される.

$$
\begin{aligned}
E_{\mathrm{VS}}^{\mathrm{B}} & =0.43 \pm 0.05 \mathrm{eV} \\
f & =0.7_{-0.4}^{+1.3} \times 10^{-3}
\end{aligned}
$$

予想されたとおり，極めて大きい VSペアの結合エネルギー が結論された。すう一つ注目されることは，式(13)におけ る $f$ の值が示しているように, $\mathrm{VS}$ ペアの移動の有効振動 数 $\nu_{\mathrm{VS}}^{*}$ が単一空孔のそれ $\nu_{\mathrm{V}}^{*}$ に較べて異常に(3桁も)低い ことである。乙のような異常な振動数は，ステージ $\delta_{1}$ に おいて屯求められて扣り(式( 5 )参照), VSペアの連続運 動に固有な特徴である.

\section{IV. 考察}

\section{1. 空孔・溶質複合体 $\mathrm{V}_{\mathrm{i}} \mathrm{S}_{\mathrm{j}}$ の物性諸元と計算機シミュ レーション}

前節までに示したように，Snや Sbなどの多価元素を 含む $\mathrm{Au}$ 稀薄合金においては，電気抵抗法による凍結空孔 の等時焼鈍回復曲線は, 純 $\mathrm{Au}$ のそれに比べると, 驚くほ よ゙複雑な様相を呈する(Fig.2参照).しかむ， Au-Sb 合 金の回復曲線と $\mathrm{Au}-\mathrm{Sn}$ 合金のそれとの間には，外見上の 著しい相違にあ拘らず，Au-Sb 合金に特有なステージ X を除けば，Table 1亿示すような各ステージの対応が良 く成り立っている. また, $\mathrm{Au}-\mathrm{Sb}$ 合金の各ステージの温 度領域は，陽電子寿命測定の助けをもかりて，Table 2 のように区分された。

ここで最む特徵的なことは, $\mathrm{Au}-\mathrm{Sb}$ 稀薄合金において 屯，Au-Sn 合金の場合と同じく，その強い結合のゆえに 単一空孔 $(\mathrm{V})$ と溶質原子 $(\mathrm{S})$ とが解離することなく $\mathrm{VS}$ ヘ
アとして連続運動を続け, 凍結空孔の回復のほぼ全過程 $\left(\delta_{1}\right.$ から $\delta_{3}$ まで)を律速していることである.乙の VS ペ アの物性諸元である移動エネルギー $E_{\mathrm{VS}}^{\mathrm{M}}$ や結合エネルギー $E_{\mathrm{VS}}^{\mathrm{B}}$ および移動における振動項 $\nu_{\mathrm{VS}}^{*}$ の評価は, ステージ $\delta_{1}$ や $\delta_{3}^{\prime}$ での等温焼鈍実験に基づいて行われた.

本節においては，今まで実験的に評価した諸元を用いて， Table 3 に示した空孔反応を利用して, 反応速度論に基 づく計算機シミュレーションを行い, 実験からは直接求め るととの困難な空孔・溶質複合体 $\mathrm{V}_{\mathrm{i}} \mathrm{S}_{\mathrm{j}}$ の物性諸元を評価 する.乙のためには, 急冷中や, 急冷後の等時焼鈍, およ び急冷後の等温焼鈍過程におりる電気抵抗変化曲線を矛盾 なく統一的に再現できるように $\mathrm{V}_{\mathrm{i}} \mathrm{S}_{\mathrm{j}}$ の諸元を設定し，計

Table 3 Vacancy reactions adopted for the computer simulation during quenching and on subsequent annealing.

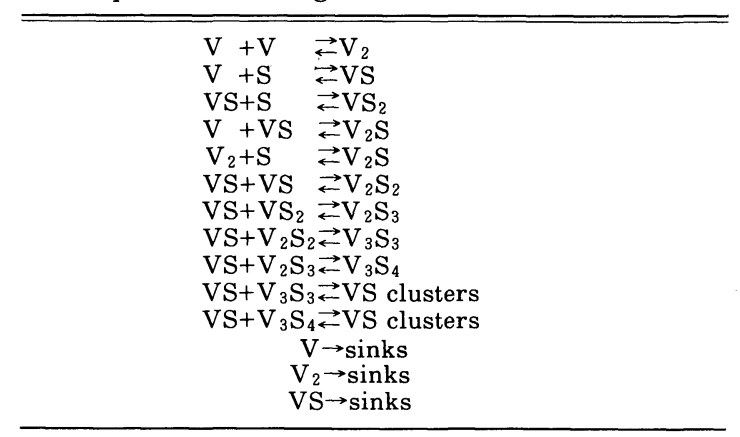

\begin{tabular}{|c|c|}
\hline $\begin{array}{l}E^{\mathrm{B}}(\mathrm{VS}) \\
E^{\mathrm{M}}(\mathrm{VS}) \\
E^{\mathrm{B}}(\mathrm{VS}+\mathrm{S}) \\
E^{\mathrm{B}}(\mathrm{VS}+\mathrm{VS}) \\
E^{\mathrm{B}}\left(\mathrm{VS}+\mathrm{VS}_{2}\right) \\
E^{\mathrm{B}}\left(\mathrm{VS}+\mathrm{V}_{2} \mathrm{~S}_{2}\right) \\
E^{\mathrm{B}}\left(\mathrm{VS}+\mathrm{V}_{2} \mathrm{~S}_{3}\right)\end{array}$ & $\begin{array}{ll}0.43 & \mathrm{eV} \\
0.59 & \\
0.17 & \\
0.54 & \\
0.57 & \\
0.88 & \\
0.93 & \end{array}$ \\
\hline $\begin{array}{l}A_{1}\left(\mathrm{VS}+\mathrm{S} \rightarrow \mathrm{VS}_{2}\right) \\
A_{1}^{\prime}\left(\mathrm{VS} S_{2} \rightarrow \mathrm{VS}+\mathrm{S}\right) \\
A_{2}\left(\mathrm{VS}+\mathrm{VS} \rightarrow \mathrm{V}_{2} \mathrm{~S}_{2}\right) \\
A_{2}^{\prime}\left(\mathrm{V}_{2} \mathrm{~S}_{2} \rightarrow \mathrm{VS}+\mathrm{VS}\right) \\
A_{2}\left(\mathrm{VS}^{2}+\mathrm{VS}_{2} \rightarrow \mathrm{V}_{2} \mathrm{~S}_{3}\right) \\
A_{2}^{\prime}\left(\mathrm{V}_{2} \mathrm{~S}_{3} \rightarrow \mathrm{VS}+\mathrm{VS}_{2}\right) \\
A_{3}\left(\mathrm{VS}^{2}+\mathrm{V}_{2} \mathrm{~S}_{2} \rightarrow \mathrm{V}_{3} \mathrm{~S}_{3}\right) \\
A_{3}^{\prime}\left(\mathrm{V}_{3} \mathrm{~S}_{3} \rightarrow \mathrm{VS}+\mathrm{V}_{2} \mathrm{~S}_{2}\right) \\
A_{3}\left(\mathrm{VS}+\mathrm{V}_{2} \mathrm{~S}_{3} \rightarrow \mathrm{V}_{3} \mathrm{~S}_{4}\right) \\
A_{3}^{\prime}\left(\mathrm{V}_{3} \mathrm{~S}_{4} \rightarrow \mathrm{VS}+\mathrm{V}_{2} \mathrm{~S}_{3}\right)\end{array}$ & $\begin{array}{l}28 \times 10^{9} \\
14 \\
22 \\
260 \\
25 \\
300 \\
10 \\
180 \\
6 \\
210\end{array}$ \\
\hline $\begin{array}{l}\rho(\mathrm{V}) \\
\rho(\mathrm{S}) \\
\rho(\mathrm{VS}) \\
\rho\left(\mathrm{VS}_{2}\right) \\
\rho\left(\mathrm{V}_{2} \mathrm{~S}_{2}\right) \\
\rho\left(\mathrm{V}_{2} \mathrm{~S}_{3}\right) \\
\rho\left(\mathrm{V}_{3} \mathrm{~S}_{3}\right) \\
\rho\left(\mathrm{V}_{3} \mathrm{~S}_{4}\right)\end{array}$ & $\begin{aligned} 1.7 & \times 10^{-8} \Omega \mathrm{m} / \text { at } \% \\
6.8 & \\
7.5 & \\
12.7 & \\
12.5 & \\
19.1 & \\
17.3 & \\
22.7 & \end{aligned}$ \\
\hline
\end{tabular}

Table 4 The set of parameters obtained from both experiments and computer simulations in the dilute $\mathrm{Au}-\mathrm{Sb}$ alloy. Here, $E^{\mathrm{B}}$ (VS) is the binding energy between a vacancy and a solute atom, $E^{\mathrm{M}}$ (VS) is the migration energy of VS pair, $E^{\mathrm{B}}$ (VS+S) is the binding energy between a VS pair and a solute atom, etc...; $A_{\mathrm{i}}$ and $A_{\mathrm{i}}^{\prime}$ are the pre-exponential factor for each vacancy reaction; $\rho$ (defect) is the resistivity contribution of the defect. 
算機シミュレーションを実施した。乙のようにして求めら れた結果は, Table 4 亿示すとおりである.乙の表には 各種の空孔・溶質複合体 $\mathrm{V}_{\mathrm{i}} \mathrm{S}_{\mathrm{j}}$ の諸元，すなわち結合エネ ルギーや移動エネルギー, 反応速度係数および電気抵抗率 への寄与なよ゙がすべて掲げてある．乙こで， $\mathrm{V}_{2} \mathrm{~S}$ の諸元 が示されていないのは, 本研究の範囲内では $\mathrm{V}_{2} \mathrm{~S}$ の濃度 は無視しうるほよ゙小さいからである。

計算機シミュレーションの仕事は, まず急冷直後の各欠 陥種の濃度を知ることである，その後，等時焼鈍あるいは 等温焼鈍曲線が，空孔反応の連立微分方程式の数值解でシ ミュレートされる.ただし，急冷途中のように空孔反応の 敏速な高温域では, 計算の効率が悪いので, 例えば式 ( 7 ) で表されるような動的平衡条件が達成されるとして，乙れ らの条件のあとで連立微分方程式を解析的に一元化し，そ の数值解を求めた. 動的平衡の条件で拘束した場合之, 自 由に解を求めた場合の計算結果は, 拘束条件を与えた温度 域が適切な場合には, 完全に一致した。本研究では, 急冷 速度が $\beta=5 \times 10^{4} \mathrm{~K} \cdot \mathrm{s}^{-1}$ の場合，その温度域を $713 \mathrm{~K}$ 以 上に設定した。

Fig.11には，上記の冷却速度で転位密度が $2 \times 10^{11} \mathrm{~m}^{-2}$ の場合，Au-0.05 at\% Sb 合金を $873 \mathrm{~K}$ から急冷したとき の, 急冷の途中に打ける各欠陥の濃度変化と, 乙の急冷に よって凍結される空孔・溶質複合体の濃度，すなわち焼鈍 開始前の各欠陥の濃度が示されている. 急冷前 $(873 \mathrm{~K})$ の 縦軸の值は, その温度での熱平衡濃度である.VSの結合 エネルギーが高いため, 熱平衡状態であ全空孔量のうち 66\% が溶質原子と結合して VSペアとなっており，急冷 直後には自由な空孔は殆ど存在しなくなる，すなわち凍結 される欠陥の大部分はVSペアであり，そのほかには，

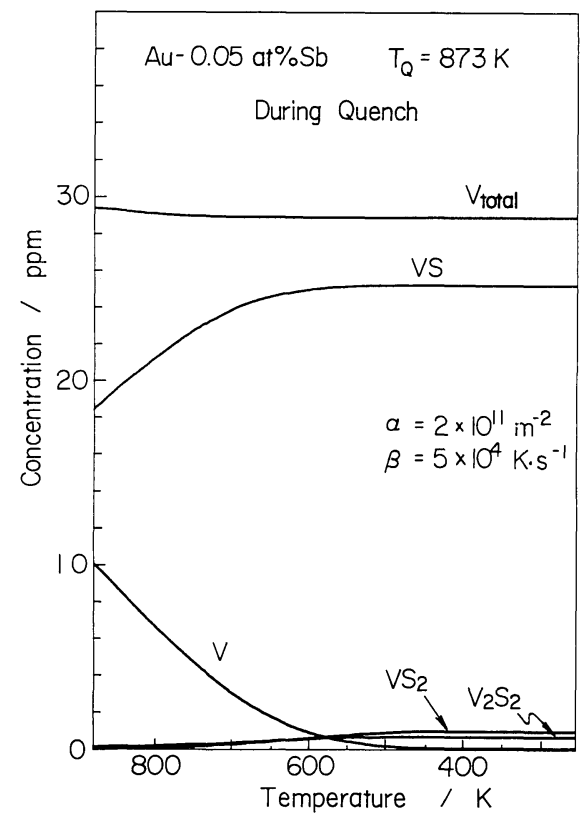

Fig.11 Computer calculation of the change in the defect concentration during quenching from $873 \mathrm{~K}$. Here, $\alpha$ is the sink density and $\beta$ is the cooling rate.
$\mathrm{VS}+\mathrm{S} \rightarrow \mathrm{VS}_{2}, \mathrm{VS}+\mathrm{VS} \rightarrow \mathrm{V}_{2} \mathrm{~S}_{2}$ の反応による少量の空孔・ 溶質複合体が含まれるのみである.

Fig.12には，Fig.11のようにして凍結された各欠陥の 濃度を初期值とし, Table 4 のパラメーターを用いて等 時焼鈍中の各欠陷種の濃度変化を計算した結果を示す。等 時焼鈍により，比較的低温加ら空孔・溶質複合体が順次形 成亡分解とを繰り返し, Table 1 の反応に従って次第に 高次の複合体が形成されていく様子がはっきりと示されて いる. Table 4 亿掲げた諸值を用いれば，Fig.13 亿例示 したように，白丸で示される等時焼鈍による電気抵抗変化 が, ステージXを除けば, 実線で示すように計算機シミュ レーションにより良く再現される.

Table 4 亿あるように, $\mathrm{Au}-\mathrm{Sb}$ 稀薄合金の場合 $\mathrm{VS}_{2}$ 以上の高次空孔・溶質複合体の電気抵抗寄与 $\rho\left(\mathrm{V}_{\mathrm{i}} \mathrm{S}_{\mathrm{j}}\right)$ は, つねに $j$ 個分の溶質原子 $\mathrm{S}$ の電気抵抗寄与 $j \cdot \rho(\mathrm{S})$ よりあ 小さい.乙のてとは, $\rho\left(\mathrm{V}_{\mathrm{i}} \mathrm{S}_{\mathrm{j}}\right) \simeq j \cdot \rho(\mathrm{S})$ である $\mathrm{Au}-\mathrm{Sn}$ 合金の場合 ${ }^{(1)}$ とは対照的であり, $\mathrm{Au}-\mathrm{Sb}$ 合金における回 復曲線が, $\mathrm{Au}-\mathrm{Sn}$ 合金とは異なり, 完全焼鈍のレベルを 大きく下まわる(Fig.2)原因となっている.

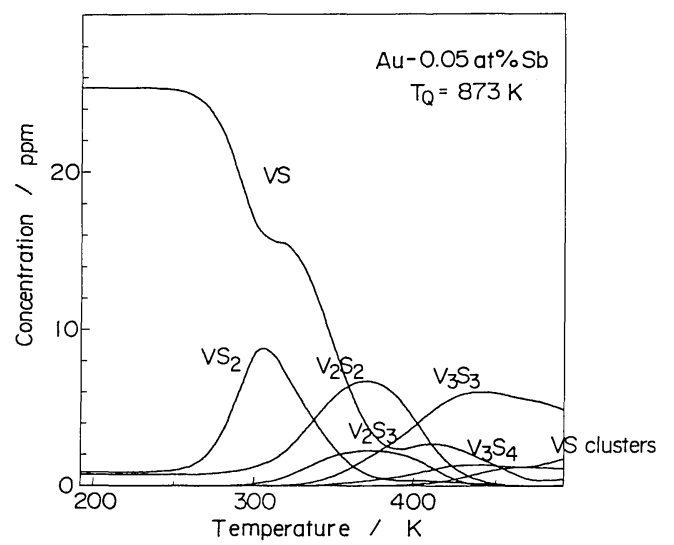

Fig.12 Computer calculation of the vacancy clustering process on isochronal annealing in a $\mathrm{Au}-0.05$ at $\% \mathrm{Sb}$ alloy quenched from $873 \mathrm{~K}$. VS clusters denote $V_{i} S_{j}(i, j \geqq 4)$.

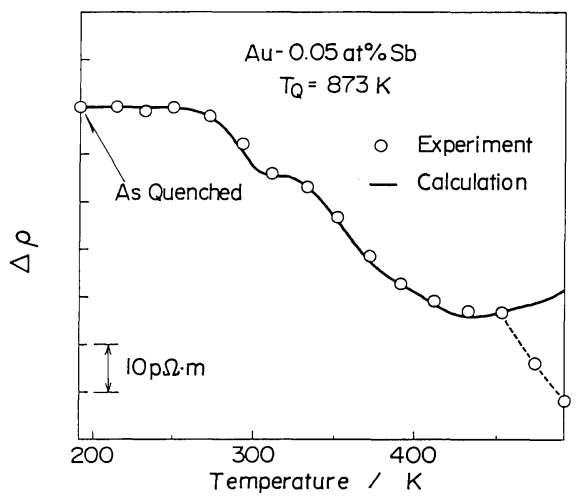

Fig.13 Computer simulation of the resistivity change based on the vacancy clustering process on isochronal annealing $(3 \mathrm{~min} / 10 \mathrm{~K})$ in a $\mathrm{Au}-$ $0.05 \mathrm{at} \% \mathrm{Sb}$ alloy quenched from $873 \mathrm{~K}$. Open circles are the experimental data. 


\section{VSペア運動の素過程}

先に述べたように，稀薄 $\mathrm{Au}-\mathrm{Sb}$ 合金の凍結空孔の回復 過程を律速しているのはVS ゚゚アの連続運動であるが，乙 のペアは $\mathrm{Au}$ 中の単一空孔や複空孔に比べて著しく小さい 移動エネルギーと振動数項を持つ. 本節では, このVSぺ ア運動の素過程と低い振動数項の起源について考察を加え る.

FCC 稀薄合金中の原子の拡散を記述する 5 ジャンプ頻 度モデル(17) では，Fig.14亿示されるように $\omega_{1}$ は溶質原 子に最近接した空孔が他の最近接位置ヘジャンプする頻度 を示し， $\omega_{2}$ は空孔之溶質原子との直接の位置交換の頻度 を示す．VSペアが解離するてとなく長距離の移動をする ためには， $\omega_{1}$ と $\omega_{2}$ のジャンプが繰り返される必要があ る。このVSペアのジャンプ頻度 $j_{\mathrm{VS}}$ は，VSペアの結合 が強く，その解離が無視できる場合には， 5 ジャンプ頻度 モデルによる溶質原子の易動度 $j_{\mathrm{S}}$ と等置され, 次式であ らわされる。

$$
j_{\mathrm{vS}} \simeq f_{2} \cdot \omega_{2}
$$

$f_{2}$ は溶質拡散の相関係数であり, VS ペアの結合が極めて 強いときには次式で近似される.

$$
f_{2} \simeq \omega_{1} /\left(\omega_{1}+\omega_{2}\right)
$$

平野らは ${ }^{(18)(19)}, \mathrm{Au}$ 之同じ 1 価貴金属で溶質拡散の挙動 に多くの類似性を有する Cuについて, 多価溶質元素であ るIn, Snの高温での溶質拡散の実験を行い，ジャンプ頻 度比 $\omega_{2} / \omega_{1}$ の温度依存性を求めている. ての結果を, 低 温部まで外挿すると, $\omega_{2} \gg \omega_{1}$ である. また, 橋本らは， 経験的 2 体間ポテンシャルを用いた格子振動数の局所的状 態密度を計算 ${ }^{(20)}, \mathrm{Cu}$ 中の ${ }^{197} \mathrm{Au}$-空孔ペアの場合も低 温で $\omega_{2} \gg \omega_{1}$ となるてとを報告している，従って，Au$\mathrm{Sb}$ 合金に扔いても, 本研究の実験温度範囲で $\omega_{2} \gg \omega_{1}$ の 関係の成り立つてとが十分推測さ机る. 従って, 式(14), (15)より $j_{\mathrm{Vs}}$ は $\omega_{1}$ と等置され，次式を得る.

$$
\nu_{\mathrm{VS}}^{*} \simeq \nu_{1}^{*}, E_{\mathrm{VS}}^{\mathrm{M}} \simeq E_{1}
$$

乙こで $\nu_{1}^{*}, E_{1}$ は $\omega_{1}$ のジャンプにかかわる有効振動数 ${ }^{(10)}$ および活性化エンタルピーである．てのようにVSペアの 運動は，溶質原子の周りを巡る $\omega_{1}$ のジャンプによって律 速されている. 従って, 式(4)扰よび（５)に示された非常 に低い活性化エネルギーと振動数之は， $\omega_{1}$ のジャンプに 関するあのであるてとがわかる。

$\mathrm{VS} ヘ ゚ ア の$ 運動に扔いて極めて特徵的なととは, 移動工 ネルギーが非常に小さいてと(式(4)参照)の他に，その振 動項が異常に低い值を持つとと(式( 5 ), (13)参照)である.

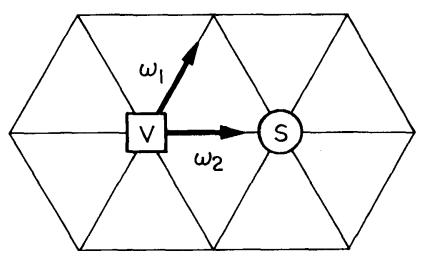

Fig.14 Vacancy jumps $\omega_{1}$ and $\omega_{2}$ in the five frequency jump model of the fcc lattice. $\mathrm{V}$ and $\mathrm{S}$ denote a vacancy and a solute atom, respectively.
VSペアの運動を律速する $\omega_{1}$ ジャンプの有効振動数は, 純 $\mathrm{Au}$ 中の空孔のジャンプに扔ける $\omega_{0}$ に比べて 3 桁す小 さい. 一般に有効振動数 $\nu^{*}$ は, 空孔と位置交換する原子 が平衡位置にある時の， $N$ 原子からなる結晶に打ける $3 N$ 個の規準振動数 $\nu_{\mathrm{j}}$ とジャンプの鞍点での $3 N-1$ 個の

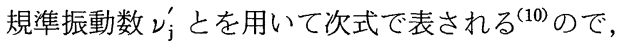

$$
\nu^{*}=\prod_{j=1}^{3 N} \nu_{j} / \prod_{j=1}^{3 N-1} \nu_{j}^{\prime}
$$

$\nu^{*}$ の値の異常を， $\nu_{j}$ の寄与と $\nu_{j}^{\prime}$ の寄与とに分けて考える てとができる. てのうち後者すなわち, 鞍点での振動数は, 溶質原子のサイズに依存するてとが予想される，ところが， 溶質原子のサイズが大きく異なる $\mathrm{Au}-\mathrm{Ge}$ 系(体積寸法因 子, $\left.\Omega_{\mathrm{SF}}=+5.54 \%{ }^{(21)}\right)$ と $\mathrm{Au}-\mathrm{Sb}$ 系 $\left(\Omega_{\mathrm{SF}}=+34.62 \%{ }^{(21)}\right)$ の 両者を比較しても， $\nu^{*}$ の值には顕著な差は認められず(1), $\nu^{*}$ の異常な値への式(17)の右辺の分母の寄与は小さいこ とが結論される. 従って式(17)右辺の分子の項を考えてみ る. この項を $\omega_{1}$ と純 $\mathrm{Au}$ の $\omega_{0}$ とで比較すると, その比 は, 純 $\mathrm{Au}$ を標準状態とした固溶による振動のエントロピー $S_{\mathrm{S}}$ と VSペアの結合エントロピー $S_{\mathrm{VS}}^{\mathrm{B}}$ を含む次式で与え られる。

$$
\left(\prod_{\mathrm{j}=1}^{3 N} \nu_{\mathrm{j}}\right)_{\mathrm{vS}} /\left(\prod_{\mathrm{j}=1}^{3 N} \nu_{\mathrm{j}}\right)_{\mathrm{v}}=\exp \left[-\left(S_{\mathrm{S}}-S_{\mathrm{VS}}^{\mathrm{B}}\right) / k T\right]
$$

$S_{\mathrm{S}}$ は溶質原子の固溶に伴って格子振動数が減少する時に 正の值をとる，一般的に $S_{\mathrm{S}}$ は，固溶エントロピーの理想 溶体からの偏倚量, すなわち過剩固溶エントロピー $\Delta S_{\mathrm{S}}^{\mathrm{xS}}$ と等置される ${ }^{(22)}$. ての $\Delta S_{\mathrm{S}}^{\mathrm{XS}}$ の值は, 熱力学的測定より $\mathrm{Au}$ 中の $\mathrm{Sn}$ については純 $\mathrm{Au}$ を標準状態として $2.4 k$ であ

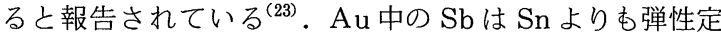
数を大きく減少させるので(24)， $S_{\mathrm{S}}$ としては $2.4 k$ 以上の 值が予想される。一方， $S_{\mathrm{VS}}^{\mathrm{B}}$ は $\mathrm{Al}$ 稀薄合金の場合には小池

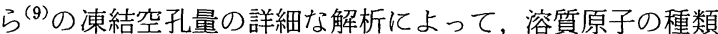
で異なるが， $-2 k \sim-5 k$ の值が報告され，振動数の著しい 低下が示唆されている。Au稀薄合金の場合も，溶質原子 が $\mathrm{Sn}$ の時には, ${ }^{119} \mathrm{Sn}$ メスバウアー効果の測定により, 単一溶質原子 $\mathrm{S}$ よりも VSペアとなった方が $\mathrm{S}$ の局所的 振動数は低下することが報告されているる ${ }^{(25)}$. てのように, 式(18)が $10^{-2} \sim 10^{-3}$ の小さい值をあつ可能性は十分ある. つまり，VSペアが平衡位置に存在するときの振動数が， $\mathrm{V}$ のみが存在するときに比へて著しく低下しているてと が，VSペア運動に扔ける極めて小さい振動数項 $\nu_{\mathrm{VS}}^{*}$ の原 因となっているもの之思われる。

\section{V. ま と め}

$\mathrm{Au}$ 中の原子空孔と多価溶質元素である $\mathrm{Ge}, \mathrm{Sn}$ 抢よび $\mathrm{Sb}$ とは極めて強い結合力をあつ．てのため，乙れらの稀 薄合金における凍結空孔の回復過程は，空孔と溶質原子が 解離するととなく連続運動するVSペアの移動によって律 速され，上り高次の空孔・溶質複合体が次々と形成と分解 とを繰り返すために, その回復曲線には特徴的な複数のス テージが出現する.

てれら一連の研究についての総括的な報告はすでになさ れているが(1)，本研究では $\mathrm{Au}-\mathrm{Sb}$ 合金について，空孔と 
溶質との相互作用, 特に VSペアの特徵とVS ゚゚ア運動に 由来する空孔・溶質複合体の物性諸元について詳細に解析 した，得られた主要な結果は以下のように要約される.

(1) Au-Sb 合金の電気抵抗回復曲線を，すでにその詳 細が解明されている Au-Sn 合金のそれと比較すると，外 見上の著しい相違(Fig.2)にも拘らず，453〜 $573 \mathrm{~K}$ の温度 領域にある異常なステージ X を除けば(Fig.6参照), 両 者は類似の反応 (Table 1)で記述される.すなわち，凍結 空孔の回復過程はVS ゚アア運動に律速される。

(2) 電気抵抗率の異常な低下を特徵とするステージ X の本性は不明であるが，溶質濃度が大きく急冷温度が高い ほど，その出現は顕著となる(Fig.3, Fig.4)．ステージX は抢そらく，Au-Sb 系に特有な規則的配列と構造緩和を 有する空孔・溶質複合体 $V_{i} S_{j}(i, j \geqq 4)$ の形成に伴う現象 であろう。

(3) 回復過程の最後の温度領域であるステージ $\delta_{3}^{\prime}$ にお いて顕著となるVSペアの分解過程の解析から, VS ゚゚ の結合エネルギーが $0.43 \pm 0.05 \mathrm{eV}$ と極めて大きいこと が明らかにされた(式(12)).

(4)乙のように空孔・溶質間の結合力が強いために, 回復過程が VS ペアの連続運動に律速されることが予想さ れ，実際にステージ $\delta_{1}$ での等温焼鈍過程の解析によりこ のことが実証され，VSペアの移動エネルギーの値として $0.59 \pm 0.02 \mathrm{eV}$ が得られた(Fig.7, Fig.8, 式(4)).

(5) VSペアの連続運動の際にその振動項が, 単一空孔 や複空孔に比べて 3 桁ほど低い異常な值をとることが見い 出された(式 (5)，(13)). その主たる原因は，VSペアが 平衡位置に存在するときの結晶全体の規準振動数の積が, $\mathrm{V}$ のみが存在するときに比べて著しく小さいためである と結論された。また，高温での拡散実験 ${ }^{(18)(19)}$ や理論計算 の結果 ${ }^{(20)}$ を本実験の温度範囲に外挿すると, $\mathrm{Au}-\mathrm{Sb}$ 合金 の VS ペア運動の律速過程は， 5 ジャンプ頻度モデルにお

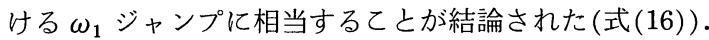

（6）反応速度論に基づく回復過程の計算機シミュレーショ ン(Fig.11, Fig.12, Fig.13)により, 実験からは直接求め るととが困難である空孔・溶質複合体 $\mathrm{V}_{\mathrm{i}} \mathrm{S}_{\mathrm{j}}$ に関する物性 諸元，すなわち結合エネルギー，電気抵抗寄与および移動 に関わる振動数項などを評価した(Table 4).

終わりに, 本研究の一部は文部省科学研究費の援助を得 て行われたので謝意を表する。

\section{文献}

(1) J.Takamura : Point Defects and Defect Interactions in Metals, Ed. by J.Takamura, M. Doyama and M.Kiritani, Univ. of Tokyo Press, Tokyo, (1982), 431.
(2) K.Nakata, K.Ikeuchi, H.Hirano, K.Furukawa and J.Takamura: Fundamental Aspects of Radiation Damage in Metals, Ed. by M.T. Robinson and F.W.Young Jr., ORNL, Oak Ridge, I, (1976), 622.

(3) 仲田清智: 京都大学工学博士学位論文, (1979).

(4) J.Bass: Phys. Rev., 137(1965), A765.

( 5 ) G.C.T.Liu, L.A.Girifalco and R.Maddin: Phys. Status Solidi, 31(1969), 303.

(6) Chr.Herzig and Th.Heumann: Z. Naturforsch., 27a(1972), 613 and 1109.

(7) Y.Shirai, K.Nakata, N.Narita, K.Furukawa and J.Takamura: Positron Annihilation, Ed. by R.R.Hasiguti and K.Fujiwara, Japan Inst. Metals, Sendai, (1979), 209.

( 8 ) Y.Shirai, K.Furukawa, J.Takamura, W.Yamada and S.Iwata: Appl. Phys., A37(1985), 65.

( 9 ) M.Koike, K.Furukawa, J.Takamura, H.Hira, N. Yamamoto and F. Nakamura : Point Defects and Defect Interactions in Metals, Ed. by J.Takamura, M.Doyama and M.Kiritani, Univ. of Tokyo Press, Tokyo, (1982), 457.

(10) G.H.Vineyard: J. Phys. Chem. Sol., 3(1957), 121.

(11) Y.Shirai, T.Hamamoto, T.Takesita, K.Furukawa and J.Takamura: Point Defects and Defect Interactions in Metals, Ed. by J.Takamura, M.Doyama and M.Kiritani, Univ. of Tokyo Press, Tokyo, (1982), 441.

(12) P.Hautöjarvi, J.Heiniö, M.Manninen and R. Nieminen : Phil. Mag., 35(1977), 973.

(13) 白井泰治 : 京都大学工学博士学位論文, (1983).

(14) J.Takamura, Y.Shirai, K.Furukawa and F. Nakamura: J. Materials Science Forum, 1518(1987), 809.

(15) A.C.Damask and G.J.Dienes: Point Defect in Metals, Gordon and Breach, New York, (1963), 88.

(16) K. P. Chik: Vacancies and Interstitials in Metals, Ed. by A.Seeger, D.Schmacher, W. Schilling and J.Diehl, North Holland, Amsterdam, (1969), 183.

(17) 例えば A.D.LeClaire : J. Nucl. Mater., 69 \& 70 (1978), 70.

(18) K.Hirano : Point Defects and Defect Interactions in Metals, Ed. by J.Takamura, M. Doyama and M.Kiritani, Univ. of Tokyo Press, Tokyo, (1982), 541.

(19) K.Hoshino, Y.Iijima and K.Hirano: Acta Met., 30(1982), 265.

(20) M.Hashimoto, Y.Ishida, R.Yamamoto and M.Doyama: Point Defects and Defect Interactions in Metals, Ed. by J.Takamura, M. Doyama and M.Kiritani, Univ. of Tokyo Press, Tokyo, (1982), 437.

(21) H.W.King: J. Mater. Science, 1(1966), 79.

(22) R. A. Swalin : Thermodynamics of Solids, John Wiley \& Sons, New York, (1962), 132.

(23) C.B.Alcock and K.T.Jacob: Acta Met., 22 (1974), 539.

（24）W.Köster：日本金属学会会報，10(1971), 429 .

(25) I.Tanaka, S.Nasu, F.E.Fujita, F.Ambe, S. Ambe and T.Okada: J. Materials Science Forum, 15-18(1987), 647. 